\title{
Effects of acid concentration, temperature, and time on recycling of post-vehicle-application lithium-ion batteries of varying chemistries
}

\author{
Haikun $\mathrm{Li}^{1} \cdot$ Lindsay M. Corneal $^{1} \cdot$ Charles R. Standridge $^{1}$
}

Received: 1 December 2014/ Accepted: 2 April 2015/Published online: 14 April 2015

(C) The Author(s) 2015. This article is published with open access at Springerlink.com

\begin{abstract}
The purpose of this project was to develop and validate a common process for separating the active materials from the copper and aluminum foils of post-vehicleapplication lithium-ion batteries. Batteries from two different manufacturers were disassembled, and anode and cathode samples were used for recycling testing. The materials tested from a third manufacturer were scraps of coated foils from the manufacturing process that had never been assembled into cells. The cathodes from each manufacturer were aluminum foils with coatings of differing chemistries. The anode foils from each manufacturer were copper with a carbon coating. The process developed used acid baths to separate the active materials from the foils. To allow for separation of the differing active materials (depending on supplier and battery chemistry) from the foils, the acids were selected to react with the aluminum and copper foils. The processes were stopped once sufficient reaction had occurred so that the coatings no longer adhered to the foils. The optimum recycling condition was identified as the lowest acid concentration, the lowest temperature, and the shortest time required for full separation of the coatings from the foils for all cell chemistries (manufacturers). Full separation of the graphite coating from the copper foils of the anodes was achieved within $35 \mathrm{~s}$ by using $0.5 \mathrm{~mol} / \mathrm{L}$ of $\mathrm{H}_{2} \mathrm{SO}_{4}$ (sulfuric acid) at $40{ }^{\circ} \mathrm{C}$. Full separation of the active materials from the aluminum foils of the cathodes was achieved within $83 \mathrm{~s}$ by using $2.0 \mathrm{~mol} / \mathrm{L}$ of $\mathrm{HNO}_{3}$ (nitric acid) at $70{ }^{\circ} \mathrm{C}$.
\end{abstract}

Lindsay M. Corneal corneall@gvsu.edu

1 School of Engineering, Grand Valley State University, Allendale, MI 49401, USA
Keywords Lithium-ion batteries - Battery recycling · Material recovery $\cdot$ Electric vehicles

\section{Introduction}

Lithium-ion batteries (LIBs) have an efficient energy storage mechanism, whose use in vehicles will continue to expand with their electrification. The Corporate Average Fuel Economy (CAFE) standards were recently approved for 2017 through 2025, with a groundbreaking 54.5 miles per gallon fuel efficiency standard by 2025 [1]. Increased electrification of vehicles is one way that these aggressive fuel efficiency standards can be met.

A fundamental question is what to do with LIB postvehicle application, which means that the battery has fallen below regulatory standards for use in on-road vehicles. Such a battery has additional economic value that can be reclaimed in one of three ways: remanufacturing for reuse in vehicles [4], repurposing the batteries into non-vehicle, stationary storage applications [5-7], and recycling when the cells are no longer able to hold a sufficient charge to support any application [8-12]. With the continued manufacturing and repurposing of LIBs, eventually each cell will no longer be useable and require recycling due to potential flammability and toxic cell components [13].

The lithium-ion batteries (LIBs) used in electric vehicles have a life span of 8-10 years [2]. Foster et al. [3] present a forecasting model which indicates that by 2035 , there will be between 1.376 million (in a pessimistic forecast) to 6.759 million (in an optimistic forecast) post-vehicle-application LIBs. In addition, these authors suggest that the only economical way to process post-vehicle-application lithium-ion batteries is through an integrated process for 
repurposing and recycling, although this integrated approach has yet to appear in the marketplace.

When the batteries are no longer sufficient for vehicle applications, the vast majority of cells comprising the battery are still able to hold a charge and are thus suitable for remanufacturing for continued use in vehicles and being repurposed for non-vehicular applications. Repurposing of post-vehicle-application LIBs, however, is not currently available in the marketplace. The remaining cells that were not capable of further use must be recycled. Current industrial practice appears to be either to recycle all the cells in the battery, which is not keeping with the principles of sustainability, or to store the battery for an indefinite period as a method of disposition is perceived to be lacking.

Currently, battery recycling companies such as Toxco charge a fee to dispose of such batteries. Disposition appears to be accomplished by crushing and shredding the batteries, attempting to recover some materials that can be sold and burying the remainder. Again, this process is not in keeping with the principles of sustainability.

LIBs produced by different manufacturers contain different active materials, particularly for the cathodes. However, in all cases, the current collecting foils are copper and aluminum. Thus, the potential for a common recycling process, which would be highly desirable, exists.

Copper accounts for approximately $11-15 \%$ of the battery by weight, and aluminum accounts for approximately 19-24\% of the battery by weight, depending on whether the battery is intended for an electric vehicle (EV), a hybrid electric vehicle (HEV), or a plug-in hybrid electric vehicle (PHEV) [14]. By breaking down the batteries and separating the coatings, copper and aluminum can be recycled. The other components such as steels, plastics, and the active materials can be either disposed of or recycled.

Most research being done in the recycling of lithium-ion batteries uses cells with $\mathrm{LiCoO}_{2}$ as the cathode active material and focuses on the recovery of cobalt and lithium [15-20], with little attention to the copper and aluminum within the cells. The methods used incorporate various acid leaching and hydro- and pyrometallurgical processes [1619] and bioleaching techniques [20].

This paper discusses the separation of the active materials from the copper and aluminum foils of post-vehicleapplication LIBs. Batteries from three different manufacturers with differing chemistries/active materials were studied. A common process was developed and validated.

\section{Materials and methods}

The batteries utilized for this work were from three different manufacturers, identified as A, B, and C. Batteries from manufacturers $\mathrm{A}$ and $\mathrm{B}$ were disassembled, and the anode and cathode samples were used for the recycling testing. The materials tested from manufacturer $\mathrm{C}$ were scraps of coated foils from the manufacturing process that had never been assembled into cells. The cathodes were aluminum foils whose coatings are of differing chemistries for each manufacturer. Manufacturer $\mathrm{A}, \mathrm{B}$, and $\mathrm{C}$ use lithium iron phosphate $\left(\mathrm{LiFePO}_{4}\right)$, lithium nickel cobalt aluminum oxide (NCA), and lithium manganese oxide $\left(\mathrm{LiMn}_{2} \mathrm{O}_{4}\right)$, respectively. The anode foils were the same for all manufacturers: copper with a carbon coating.

Acid baths were used to separate the active materials from the foils. The acids were selected to react with the aluminum and copper foils. Thus, the same acids were used for separation of foil coatings of varying chemistries which depended on the supplier. By focusing on the reaction with the aluminum and copper rather than the coating materials, it was hypothesized that the same process would be effective for batteries from the different suppliers.

Sulfuric acid $\left(\mathrm{H}_{2} \mathrm{SO}_{4}\right)$ was selected because of its reactivity with copper, as shown in Eq. 1. It was hypothesized that the $\mathrm{H}_{2} \mathrm{SO}_{4}$ would react with the copper foil, thereby weakening the adhesion of the anode coatings to the foil.

$$
\begin{aligned}
\mathrm{Cu}(\mathrm{s})+2 \mathrm{H}_{2} \mathrm{SO}_{4}(\mathrm{aq}) \rightarrow & 2 \mathrm{H}_{2} \mathrm{O}(\mathrm{l})+\mathrm{SO}_{2}(\mathrm{~g}) \\
& +\mathrm{CuSO}_{4}(\mathrm{aq})
\end{aligned}
$$

Nitric acid $\left(\mathrm{HNO}_{3}\right)$ was selected for the reaction with aluminum as shown in Eq. 2. The intent was for the $\mathrm{HNO}_{3}$ to react with the aluminum foil, thereby weakening the adhesion of the carbon coating to the foil.

$2 \mathrm{Al}(\mathrm{s})+6 \mathrm{HNO}_{3}(\mathrm{aq}) \rightarrow 2 \mathrm{Al}\left(\mathrm{NO}_{3}\right)_{3}(\mathrm{aq})+3 \mathrm{H}_{2}(\mathrm{~g})$

Because $\mathrm{SO}_{2}$ and $\mathrm{H}_{2}$ gases are products of the above reactions, all tests were conducted in a fume hood. Experiments were designed and conducted to find the lowest acid concentration, the lowest temperature, and the shortest time required for full separation of the coatings from the foils for each of the battery chemistries (manufacturers). Such a combination was hypothesized to result in the lowest cost of recycling. Experiments for each battery chemistry were used to determine the shortest separation time for the varying combinations of acid concentration and temperature.

Sulfuric acid has been shown to react with copper in concentrations as low as $0.5 \mathrm{~mol} / \mathrm{L}$ [21]. Therefore, for separation of the carbon coatings from the copper foils, $50 \mathrm{~mL}$ of $2.0,1.0$, and $0.5 \mathrm{~mol} / \mathrm{L}$ solutions of sulfuric acid (95.0-98.0 \%, Sigma-Aldrich Co, St. Louis, MO) were prepared. While stirring, $5 \mathrm{~g}$ of the coated copper foils were placed in the sulfuric acid solution. The time taken for the coatings to separate from the foils was recorded. Tests were conducted at $25,30,40$, and $50{ }^{\circ} \mathrm{C}$. The tests were repeated with samples from each manufacturer. 
For separation of the cathode active coatings from the aluminum foils, $50 \mathrm{~mL}$ of $2.0,1.0$, and $0.5 \mathrm{~mol} / \mathrm{L}$ solutions of nitric acid (70\%, Sigma-Aldrich Co, St. Louis, MO) were prepared. While stirring, $3 \mathrm{~g}$ of the coated aluminum foils were placed in the nitric acid solution. The time taken for the coatings to separate from the foils was recorded. Tests were conducted at $25,30,40,50,60$, and $70{ }^{\circ} \mathrm{C}$. The testing combinations were repeated for each manufacturer.

The purpose of the testing was to identify a common process and process parameters for LIB recycling for all manufacturers. Thus, if it was found that the samples from a particular manufacturer were separating at faster times, the number of test combinations was reduced so that higher concentrations and temperatures were not tested if the lower concentrations and temperatures for a particular manufacturer were not limiting the separation time when compared to the time required for the samples from the other manufacturers.

\section{Results and discussion}

\section{Separation of carbon coatings from copper foils}

Upon immersion of the coated copper foils into the sulfuric acid solutions, bubbles of $\mathrm{SO}_{2}$ gas formed on the surface. There was also minor heat dissipation (approximately $4{ }^{\circ} \mathrm{C}$ temperature rise) during the tests, and the solution turned slightly blue, indicating the formation of copper sulfate $\left(\mathrm{CuSO}_{4}\right)$ due to the reaction of the copper with the sulfuric acid. This reaction did cause a degradation of the adhesion of the carbon coating to the copper foils, as was intended. The $\mathrm{H}_{2} \mathrm{SO}_{4}$ concentrations, temperatures, and times required for full separation of the coating from the copper foils for the samples from manufacturers A, B and C are given in Tables 1, 2, and 3, respectively.

Increasing the $\mathrm{H}_{2} \mathrm{SO}_{4}$ concentration had very little effect on decreasing the separation times. At temperatures of 25 and $30{ }^{\circ} \mathrm{C}$, increasing the sulfuric acid concentration from 0.5 to $1 \mathrm{~mol} / \mathrm{L}$ and $2 \mathrm{~mol} / \mathrm{L}$ resulted in separation times of 7-14 s faster for samples from manufacturer $\mathrm{A}$ and separation times of 5-23 s faster for samples from manufacturer $\mathrm{C}$. However, when the temperature was raised to $50{ }^{\circ} \mathrm{C}$, increasing the concentration had no effect on decreasing the separation times.

The separation of the carbon coatings from the copper foils occurred within $65 \mathrm{~s}$ for all concentration and temperature conditions tested. The fastest separation time of $5 \mathrm{~s}$ occurred with the samples from manufacturer B, with an $\mathrm{H}_{2} \mathrm{SO}_{4}$ concentration of $0.5 \mathrm{~mol} / \mathrm{L}$ and temperature of $25^{\circ} \mathrm{C}$. For the samples from the other manufacturers, higher temperatures were required to achieve the fastest
Table 1 Separation times for carbon coatings from copper foils from manufacturer $\mathrm{A}$ for varying $\mathrm{H}_{2} \mathrm{SO}_{4}$ concentrations and temperatures

\begin{tabular}{lll}
\hline $\mathrm{H}_{2} \mathrm{SO}_{4}$ concentration $(\mathrm{mol} / \mathrm{L})$ & Temperature $\left({ }^{\circ} \mathrm{C}\right)$ & Separation time $(\mathrm{s})$ \\
\hline 2 & 25 & 57 \\
2 & 30 & 49 \\
2 & 40 & 37 \\
1 & 25 & 50 \\
1 & 30 & 40 \\
1 & 40 & 37 \\
0.5 & 25 & 64 \\
0.5 & 30 & 47 \\
0.5 & 40 & 35 \\
\hline
\end{tabular}

Table 2 Separation times for carbon coatings from copper foils from manufacturer $\mathrm{B}$ for varying $\mathrm{H}_{2} \mathrm{SO}_{4}$ concentrations and temperatures

\begin{tabular}{lll}
\hline $\mathrm{H}_{2} \mathrm{SO}_{4}$ concentration $(\mathrm{mol} / \mathrm{L})$ & Temperature $\left({ }^{\circ} \mathrm{C}\right)$ & Separation time $(\mathrm{s})$ \\
\hline 0.5 & 25 & 5 \\
\hline
\end{tabular}

Table 3 Separation times for carbon coatings from copper foils from manufacturer $\mathrm{C}$ for varying $\mathrm{H}_{2} \mathrm{SO}_{4}$ concentrations and temperatures

\begin{tabular}{lll}
\hline $\mathrm{H}_{2} \mathrm{SO}_{4}$ concentration (mol/L) & Temperature $\left({ }^{\circ} \mathrm{C}\right)$ & Separation time $(\mathrm{s})$ \\
\hline 2 & 30 & 35 \\
2 & 40 & 29 \\
2 & 50 & 20 \\
1 & 30 & 53 \\
1 & 40 & 25 \\
1 & 50 & 16 \\
0.5 & 30 & 58 \\
0.5 & 40 & 26 \\
0.5 & 50 & 16 \\
\hline
\end{tabular}

separation times. For the samples from manufacturer A, the shortest separation time was $35 \mathrm{~s}$ using an $\mathrm{H}_{2} \mathrm{SO}_{4}$ concentration of $0.5 \mathrm{~mol} / \mathrm{L}$ at a temperature of $40{ }^{\circ} \mathrm{C}$. For the samples from manufacturer $\mathrm{C}$, the shortest separation time was $16 \mathrm{~s}$ at both the 1 and $0.5 \mathrm{~mol} / \mathrm{L}$ concentrations, at a temperature of $50{ }^{\circ} \mathrm{C}$.

It was noted that there were separation times for the samples from manufacturer $\mathrm{C}$ at lower temperatures that were still below the shortest separation time for the samples from manufacturer $\mathrm{A}$. Using the same $\mathrm{H}_{2} \mathrm{SO}_{4}$ concentration of $0.5 \mathrm{~mol} / \mathrm{L}$ and temperature of $40{ }^{\circ} \mathrm{C}$, which was identified as the optimum condition for the samples from manufacturer A, the separation time for the samples from manufacturer $\mathrm{C}$ was $26 \mathrm{~s}$. Using common conditions of an $\mathrm{H}_{2} \mathrm{SO}_{4}$ concentration of $0.5 \mathrm{~mol} / \mathrm{L}$ at a temperature of $40{ }^{\circ} \mathrm{C}$ results in the separation of samples from all manufacturers within $35 \mathrm{~s}$. 
Table 4 Separation times for cathode active material coatings from aluminum foils from manufacturer A for varying $\mathrm{HNO}_{3}$ concentrations and temperatures

\begin{tabular}{lll}
\hline $\mathrm{HNO}_{3}$ concentration $(\mathrm{mol} / \mathrm{L})$ & Temperature $\left({ }^{\circ} \mathrm{C}\right)$ & Separation time $(\mathrm{s})$ \\
\hline 2 & 25 & 55 \\
2 & 30 & 46 \\
1 & 25 & 54 \\
1 & 30 & 43 \\
1 & 40 & 35 \\
0.5 & 25 & 67 \\
0.5 & 30 & 62 \\
0.5 & 40 & 40 \\
\hline
\end{tabular}

Table 5 Separation times for cathode active material coatings from aluminum foils from manufacturer $\mathrm{B}$ for varying $\mathrm{HNO}_{3}$ concentrations and temperatures

\begin{tabular}{lll}
\hline $\mathrm{HNO}_{3}$ concentration (mol/L) & Temperature $\left({ }^{\circ} \mathrm{C}\right)$ & Separation time $(\mathrm{s})$ \\
2 & 25 & 35 \\
2 & 30 & 32 \\
2 & 40 & 26 \\
1 & 25 & 41 \\
1 & 30 & 39 \\
1 & 40 & 29 \\
0.5 & 25 & 44 \\
0.5 & 30 & 40 \\
0.5 & 40 & 33 \\
\hline
\end{tabular}

\section{Separation of cathode active material coatings from aluminum foils}

Upon immersion of the coated aluminum foils into the nitric acid solutions, bubbles of $\mathrm{H}_{2}$ gas formed on the surface of the aluminum foils. There was also minor heat dissipation (approximately $2{ }^{\circ} \mathrm{C}$ temperature rise) during the tests. The reaction between the $\mathrm{HNO}_{3}$ and aluminum resulted in a degradation of the adhesion of the cathode coatings to the foils, as was intended. The $\mathrm{HNO}_{3}$ concentrations, temperatures, and times required for full separation of the coating from the aluminum foils for the samples from manufacturers $\mathrm{A}, \mathrm{B}$ and $\mathrm{C}$ are given in Tables 4,5 and 6 , respectively.

For the conditions tested, the separation of the cathode active material coatings from the aluminum foils tended to take longer time than the time required for the separation of the carbon coatings from the copper foils for each manufacturer. The fastest separation time of $26 \mathrm{~s}$ was achieved with an $\mathrm{HNO}_{3}$ concentration of $2 \mathrm{~mol} / \mathrm{L}$ at $40{ }^{\circ} \mathrm{C}$ for the samples from manufacturer B. For the samples from manufacturer $\mathrm{A}$, an $\mathrm{HNO}_{3}$ concentration of $1 \mathrm{~mol} / \mathrm{L}$ at $40{ }^{\circ} \mathrm{C}$ resulted in a separation time of $35 \mathrm{~s}$. The samples from
Table 6 Separation times for cathode active material coatings from aluminum foils from manufacturer $\mathrm{C}$ for varying $\mathrm{HNO}_{3}$ concentrations and temperatures

\begin{tabular}{lll}
\hline $\mathrm{HNO}_{3}$ concentration $(\mathrm{mol} / \mathrm{L})$ & Temperature $\left({ }^{\circ} \mathrm{C}\right)$ & Separation time $(\mathrm{s})$ \\
\hline 2 & 50 & 180 \\
2 & 60 & 161 \\
2 & 70 & 83 \\
1 & 50 & 273 \\
1 & 60 & 210 \\
1 & 70 & 120 \\
0.5 & 50 & $>300.00$ \\
0.5 & 60 & 219 \\
0.5 & 70 & 125 \\
\hline
\end{tabular}

manufacturer $\mathrm{C}$ had much longer separation times than the samples from the other manufacturers. The shortest separation time for the samples from manufacturer $\mathrm{C}$ was $83 \mathrm{~s}$, using an $\mathrm{HNO}_{3}$ concentration of $2 \mathrm{~mol} / \mathrm{L}$ at $70{ }^{\circ} \mathrm{C}$.

The common condition for the separation of the active materials from the aluminum foils would then be to use an $\mathrm{HNO}_{3}$ concentration of $2 \mathrm{~mol} / \mathrm{L}$ at $70{ }^{\circ} \mathrm{C}$, and the separation would occur within $83 \mathrm{~s}$ for samples from all manufacturers. It would also be possible, however, to use lower temperatures which would work for the samples from manufacturers A and B but would approximately double the separation time for the samples from manufacturer C. An $\mathrm{HNO}_{3}$ concentration of $2 \mathrm{~mol} / \mathrm{L}$ at $50{ }^{\circ} \mathrm{C}$ would be able to achieve separation for the samples from manufacturer $\mathrm{C}$ in $180 \mathrm{~s}$ (3 $\mathrm{min})$.

\section{Future work}

These results have shown that it is possible to identify a common acid concentration and temperature that will separate the differing active materials from the current collecting foils in a reasonable length of time (within 3 min). Once separated, the copper and aluminum foils can then be recycled. The next step will be to consider the other components of the cells such as steels, plastics, and the active materials. The recycling or disposal of each of these must be considered.

\section{Summary and conclusions}

The use of acid baths to separate the active material coatings from the collecting foils of post-vehicle-application LIBs of varying chemistries from three different manufacturers was evaluated. A process was developed and verified to separate the carbon coatings from the copper foils of the anode using sulfuric acid. The reaction between the $\mathrm{H}_{2} \mathrm{SO}_{4}$ and the copper resulted in the 
degradation of the adhesion of the carbon coatings to the foils. The combination of $\mathrm{H}_{2} \mathrm{SO}_{4}$ concentration of $0.5 \mathrm{~mol} /$ $\mathrm{L}$ and temperature of $40{ }^{\circ} \mathrm{C}$ resulted in the shortest time for full separation of the coating from the foil, within $35 \mathrm{~s}$. A method was identified to separate the coatings from the aluminum foils of the cathodes using nitric acid.

The reaction between the $\mathrm{HNO}_{3}$ and aluminum weakened the adhesion of the cathode coatings to the foils, resulting in their separation. The differences between the LIB chemistries from the three manufacturers resulted in greater variations in the conditions required for full separation of the cathode active material coatings than of the anode coatings. The results of testing various $\mathrm{HNO}_{3}$ concentrations and temperatures identified that full separation of the coatings from the aluminum foils was possible within $83 \mathrm{~s}$ for samples from all manufacturers by using an $\mathrm{HNO}_{3}$ concentration of $2 \mathrm{~mol} / \mathrm{L}$ at $70{ }^{\circ} \mathrm{C}$.

Given these results, the development of a common process with common parameter values for recycling the valuable materials in post-vehicle-application LIBs of varying chemistries that cannot be remanufactured or repurposed is shown to be possible.

Acknowledgments The authors acknowledge the Michigan Department of Transportation and the US Department of Transportation via the Mineta National Transit Research Consortium (MNTRC project\#1137) for their financial support of this work. We would also like to thank Sybesma's Electronics for their support of this work.

Open Access This article is distributed under the terms of the Creative Commons Attribution 4.0 International License (http:// creativecommons.org/licenses/by/4.0/), which permits unrestricted use, distribution, and reproduction in any medium, provided you give appropriate credit to the original author(s) and the source, provide a link to the Creative Commons license, and indicate if changes were made.

\section{References}

1. Center for Climate and Energy Solutions, Federal Vehicle Standards. http://www.c2ES.org/federal/executive/vehicle-standards (2014). Accessed 27 September 2014

2. Richa, K., Babbitt, C.W., Gaustad, G., Wang, X.: A future perspective on lithium-ion battery waste flows from electric vehicles. Resour. Conserv. Recycl. 83, 63-76 (2014)

3. Foster, M., Isely, P., Standridge, C.R., Hasan, MdM: Feasibility assessment of remanufacturing, repurposing, and recycling of end of vehicle application lithium-ion batteries. J. Ind. Eng. Manag. 7, 698-715 (2014)
4. Schneider, E.L., Kindlein, W., Souza, S., Malfatti, C.F.: Assessment and reuse of secondary batteries cells. J. Power Sour. 189, 1264-1269 (2009)

5. Andrijanovits, A., Hoimoja, H., Vinnikov, D.: Comparative review of long-term energy storage technologies for renewable energy systems. Electron. Electr. Eng. 118, 21-26 (2012)

6. Yang, Z., Liu, J., Baskaran, S., Imhoff, C.H., Holladay, J.D.: Enabling renewable energy and the future grid with advanced electricity storage. JOM 62, 14-23 (2012)

7. Diaz-Gonzalez, F., Sumper, A., Gomis-Bellmunt, O., VillafafilaRobles, R.: A review of energy storage technologies for wind power applications. Renew. Sustain Energy Rev. 16, 2154-2171 (2012)

8. Gratz, E., Sa, Q., Apelian, D., Wang, Y.: A closed loop process for recycling spent lithium ion batteries. J. Power Sour. 262, 255-262 (2014)

9. Georgi-Maschler, T., Friedrich, B., Weyhe, R., Heegn, H., Rutz, M.: Development of a recycling process for $\mathrm{Li}$-ion batteries. J. Power Sour. 207, 173-182 (2012)

10. Paulino, J.F., Busnardo, N.G., Afonso, J.C.: Recovery of valuable elements from spent Li-Batteries. J. Hazard. Mater. 150, 843-849 (2008)

11. Lain, M.J.: Recycling of lithium ion cells and batteries. J. Power Sour. 97-98, 736-738 (2001)

12. Contestabile, M., Panero, S., Scrosati, B.: A laboratory-scale lithium-ion battery recycling process. J. Power Sour. 92, 65-69 (2001)

13. Standridge, C.R., Corneal, L.: Remanufacturing, repurposing, and recycling of post-vehicle-application lithium-ion batteries. Mineta National Transit research consortium, San Jose, CA. transweb.sjsu.edu/project/1137.html (2014). Accessed 25 November 2014

14. Dunn, J.B., Gaines, L., Barnes, M., Sullivan, J., Wang, M.: Material and energy flows in the materials production, assembly, and end-of-life stages of the automotive lithium-ion battery life cycle. Energy. Sys. Division Argonne. Natl. Lab. Rep. (2012)

15. Lain, M.J.: Recycling of lithium ion cells and batteries. J. Power Sour. 97-98, 736-738 (2001)

16. Zhang, P., Yokoyama, T., Itabashi, O., Suzuki, T.M., Inoue, K.: Hydrometallurgical process for recovery of metal values from spent lithium-ion secondary batteries. Hydrometallurgy 47, 259-271 (1998)

17. Dorella, G., Mansur, M.: A study of the separation of cobalt from spent Li-ion battery residues. J. Power Sour. 170, 210-215 (2007)

18. Li, L., Ge, J., Chen, R., Wu, F., Chen, S., Zhang, X.: Environmental friendly leaching reagent for cobalt and lithium recovery from spent lithium-ion batteries. Waste Manag. 30, 2615-2621 (2010)

19. Georgi-Maschler, T., Friedrich, B., Weyhe, R., Heegn, H., Rutz, M.: Development of a recycling process for $\mathrm{Li}$-ion batteries. J. Power Sour. 207, 173-182 (2012)

20. Xin, B.P., Zhang, D., Zhang, X., Xia, Y., Wu, F., Chen, S., Li, L.: Bioleaching mechanism of $\mathrm{Co}$ and $\mathrm{Li}$ from spent lithium-ion battery by the mixed culture of acidophilic sulfur-oxidizing and iron-oxidizing bacteria. Bioresour. Technol. 100, 6163-6169 (2009)

21. Benali, O., Larabi, L., Harek, Y.: Inhibiting effects of 2-mercapto-1-methylimidazole on copper corrosion in $0.5 \mathrm{M}$ sulfuric acid. J. Saudi Chem. Soc. 14, 231-235 (2010) 